\title{
KNOWLEDGE OF CORONARY ARTERIOSCLEROSIS RISK FACTORS AND THEIR OCCURRENCE AND THE LIFESTYLES OF THE FIRST-YEAR MEDICAL STUDENTS
}

\section{ZNAJOMOŚĆ CZYNNIKÓW RYZYKA MIAŻDŻYCY TĘTNIC WIEŃCOWYCH, ICH WYSTĘPOWANIE ORAZ STYL ŻYCIA PROWADZONY PRZEZ STUDENTÓW PIERWSZEGO ROKU MEDYCYNY}

\author{
Józefa Dąbek ${ }^{1(A, B, C, D, E, F, G)}$, Paweł Skorus ${ }^{2(B, C, D, E, F, G)}$, Tomasz Lepich ${ }^{3(B, C, D, E, F, G)}$, \\ Grzegorz Bajor $^{3(\mathrm{D})}$, Zbigniew Gąsior ${ }^{1(\mathrm{D})}$ \\ ${ }^{1}$ Department of Cardiology, Medical University of Silesia, Poland \\ ${ }^{2}$ Students Scientific Circle at the Chair and Department of Cardiology of School of Health Sciences, \\ Medical University of Silesia in Katowice, Poland \\ ${ }^{3}$ Department of Human Anatomy, Medical University of Silesia, Poland
}

Authors' contribution Wkład autorów: A. Study design/planning zaplanowanie badań B. Data collection/entry zebranie danych C. Data analysis/statistics dane - analiza i statystyki D. Data interpretation interpretacja danych E. Preparation of manuscript przygotowanie artykułu F. Literature analysis/search wyszukiwanie i analiza literatury G. Funds collection zebranie funduszy
Tables: 1

Figures: 13

References: 26

Submitted: 2016 Sep 30

Accepted: 2016 Oct 31
Summary

Background. Coronary arteriosclerosis risk factors increase the probability of the coronary heart disease and accompanying complications to a significant extent, acting independently from other circumstances.

Material and methods. The study was conducted in a group of 250 students of the 1 st-year medical studies, using an independently prepared questionnaire relating to the risk factors and particular lifestyles.

Results. 1. Level of knowledge of the examined students on coronary arteriosclerosis risk factors: obesity - 250(100\%); reduced physical activity - 240(96\%); smoking - 230(92\%); unhealthy diet - 223(89\%); elevated LDL cholesterol concentration - 218(87\%); arterial hypertension - $210(84 \%)$. 2. Incidence of coronary arteriosclerosis risk factors in students: strong family history - 75(30\%); excessive stress - 50(20\%); reduced physical activity 190(76\%); smoking - 55(22\%), alcohol abuse - 95(38\%). 3. Lifestyle of the examined group of students: eating fast-food - $180(72 \%)$; drinking energetic beverages - 82(33\%); "trying" and using drugs - 88(35\%); insufficient amount of sleep - 190(76\%).

Conclusions. 1. Level of the examined students' knowledge on coronary arteriosclerosis risk factors is satisfactory. 2. Despite the satisfactory level of knowledge on risk factors, their incidence in the tested group is significant. 3. Majority of the examined students live a healthy lifestyle.

Keywords: risk factors, lifestyle, coronary disease

\section{Streszczenie}

Wstep. Czynniki ryzyka miażdżycy tetnic wieńcowych to czynniki, które działając niezależnie od innych okoliczności, zwiększają istotnie prawdopodobieństwo wystąpienia choroby wieńcowej i jej powikłań.

Materiał i metody. Badanie przeprowadzono w grupie 250 studentów 1. roku medycyny za pomocą samodzielnie przygotowanej ankiety dotyczącej czynników ryzyka i stylu życia.

Wyniki. 1. Znajomość czynników ryzyka miażdżycy tętnic wieńcowych przez studentów badanej grupy: otyłość - 250 (100\%), mała aktywność fizyczna - 240 (96\%), palenie papierosów - 230 (92\%), nieprawidłowe odżywianie - 223 (89\%), zwiększone stężenie cholesterolu LDL - 218 (87\%), nadciśnienie tętnicze - 210 (84\%). 2. Występowanie czynników ryzyka miażdżycy tettnic wieńcowych u studentów 1. roku medycyny: obciążający wywiad rodzinny - 75 (30\%), nadmierny stres - 50 (20\%), mała aktywność fizyczna - 190 (76\%), palenie papierosów - $55(22 \%)$, nadużywanie alkoholu - 95 (38\%). 3. Styl życia badanej grupy studentów: spożywanie posiłków fast-foodowych - 180 (72\%), spożywanie napojów energetyzujących - 82 (33\%), „próbowanie” i okresowe stosowanie narkotyków - 88 (35\%), niewystarczająca długość snu - 190 (76\%).

Wnioski. 1. Znajomość czynników ryzyka miażdżycy tętnic wieńcowych przez studentów badanej grupy jest zadowalająca. 2. Pomimo zadowalającej znajomości czynników ryzyka ich występowanie w badanej grupie jest znaczące. 3. Większość badanych studentów prowadzi „zdrowy” styl życia.

Słowa kluczowe: czynniki ryzyka, styl życia, choroba wieńcowa

Dąbek J, Skorus P, Lepich T, Bajor G, Gąsior Z. Knowledge of coronary arteriosclerosis risk factors and their occurrence and the lifestyles of the first-year medical students. Health Prob Civil. 2018; 12(2): 78-87. https://doi.org/10.5114/hpc.2018.75489

Address for correspondence / Adres korespondencyjny: Józefa Dąbek, Department of Cardiology, Medical University of Silesia, Ziołowa 47 street, $40-635$ Katowice, Poland, e-mail: jdabek@sum.edu.pl, phone: +48323598530

Copyright: (C) Pope John Paul II State School of Higher Education in Biała Podlaska, Józefa Dąbek, Paweł Skorus, Tomasz Lepich, Grzegorz Bajor, Zbigniew Gąsior. This is an Open Access journal, all articles are distributed under the terms of the Creative Commons Attribution-NonCommercial-ShareAlike 4.0 International (CC BY-NC-SA 4.0) License (http://creativecommons.org/licenses/by-nc-sa/4.0/), allowing third parties to copy and redistribute the material in any medium or format and to remix, transform, and build upon the material, provided the original work is properly cited and states its license. 


\section{Introduction}

Prevalence of cardiovascular diseases is currently linked to civilisational progress, connected primarily with one's lifestyle. According to epidemiological data and scientific reports, each year the cardiovascular diseases contribute to the deaths of about 17 million persons around the world. Only in the European Union, they cause fatalities amounting to $24 \%$, i.e. around 4 million people per year [1]. Also in Poland, the cardiovascular diseases occupy the first place in the rank of most common causes of deaths, overtaking cancer, despite the fact that their figures are decreasing. The number of Polish patients suffering from chronic coronary heart disease is estimated at 1.2 million individuals. Among the cardiovascular system conditions, the most common cause of death is the coronary heart disease and its complications, including a heart attack.

The ischemic heart disease is a broad term, which comprises all conditions of myocardial ischemia, regardless of the reason. The coronary artery disease includes conditions of myocardial ischemia caused by sclerotic vasoconstrictive changes in coronary arteries. In about $98 \%$ of cases, myocardial ischemia is conditioned by coronary arteriosclerosis, while the remaining $2 \%$ are due to other causes.

Coronary failure is a set of symptoms that result from disproportions between supply and the cardiac muscle's current demand for oxygen and energetic compounds. In physiological conditions, during an increased oxygen demand exhibited by the cardiac muscle (increase in the heart rate and tone of walls, elevated contractility), there is an increase in the flow rate in coronary arteries. If significant hemodynamic stenoses appear in epicardial arteries, the flow rate in the resting state may be maintained through compensational distension of a vascular bed, beyond the spot of stenosis. Then, a reduction of a coronary reserve takes place, resulting in incapability of providing oxygen in case of an increase of the myocardium demand.

Symptoms of angina pectoris appear when, as a result of stenoses in coronary arteries, the demand for oxygen and nutritious substances in the cardiac muscles is not covered to the fullest extent. Elevated vasoreactivity (a vasospasm in the spot of stenosis) of coronary arteries may also reduce blood flow, both in standard and increased demand conditions. A systolic component of a vessel seems to be responsible for periodic, seasonal and emotional character of the angina pectoris condition. It needs to be emphasised that dependencies between the presence of the stenosis and the systolic component of the vessel may change in each case. Cracks or erosion of atheromatous plaque contribute to generating blood clots which, as a consequence, may reduce or break blood flow in the vessel [2].

While acting independently from other circumstances, Risk factors cause a significant increase in the probability of a particular pathology, for example, a cardiovascular disease [3].

Extensive and long-standing studies have led to the identification of about 300 arteriosclerosis factors, which are more or less related to an increase of human proneness to clinically significant circulatory system diseases $[4]$.

A major division of risk factors depends on how likely they are alterable. According to that principle, the first group consists of non-modifiable factors, which are resistant to all actions that would change their atherogenic effects. They comprise individual elements, such as age, sex, strong family history and metabolic disturbances determined genetically. The other group of risk factors contains those prone to modifiable actions, such as hypercholesterolemia, diabetes, arterial hypertension, malnutrition, smoking, physical inactivity and obesity. The fact that people can limit the adverse influences of the alterable factors on their health, through changing behaviour and lifestyle, should be motivating [5-6].

\section{Material and methods}

The examined group was composed of $250(\mathrm{n}=100 \%)$ students of the first-year medical studies, aged 19-26 $(\bar{x}=20.956$ years old; $S D=1.530)$. Among them, there were $145(58 \%)$ women and $105(42 \%)$ men. The study was conducted in 2014 using an independently prepared survey questionnaire related to knowledge on coronary arteriosclerosis risk factors and their incidence in the examined students, as well as the data on their lifestyles. The questionnaire was anonymous, and participation in it voluntary. The questions included in the survey were closed ones, with an option to select one or several answers.

The results have been compiled in a spreadsheet. The analysis was carried out through calculating summary and descriptive statistics. As for the homogeneity of the examined group, there was no outliers analysis performed [7]. 


\section{Results}

\section{General characteristics of the first-year medical students}

The general characteristics of the examined students are presented in Table 1.

Table 1. General characteristics of the examined group of first-year medical students

\begin{tabular}{|c|c|c|c|}
\hline \multicolumn{2}{|c|}{ Examined group } & n; & $\%$ \\
\hline \multicolumn{2}{|c|}{ Size of the examined group $n, \%$ of the group } & 250 & $(100 \%)$ \\
\hline \multirow{2}{*}{$\operatorname{sex}$} & female & 145; & $(58 \%)$ \\
\hline & male & 105; & $(42 \%)$ \\
\hline age in years & $\overline{\mathbf{x}}$ & \multicolumn{2}{|c|}{ \pm SD } \\
\hline $19-26$ & 20.956 & \multicolumn{2}{|c|}{1.530} \\
\hline
\end{tabular}

In the examined group women outnumbered men.

\section{Characteristics of the first-year medical students with regard to their knowledge on coronary arteriosclerosis risk factors}

The characteristics of the examined students with regard to their knowledge on coronary disease factors are presented in Figure 1.

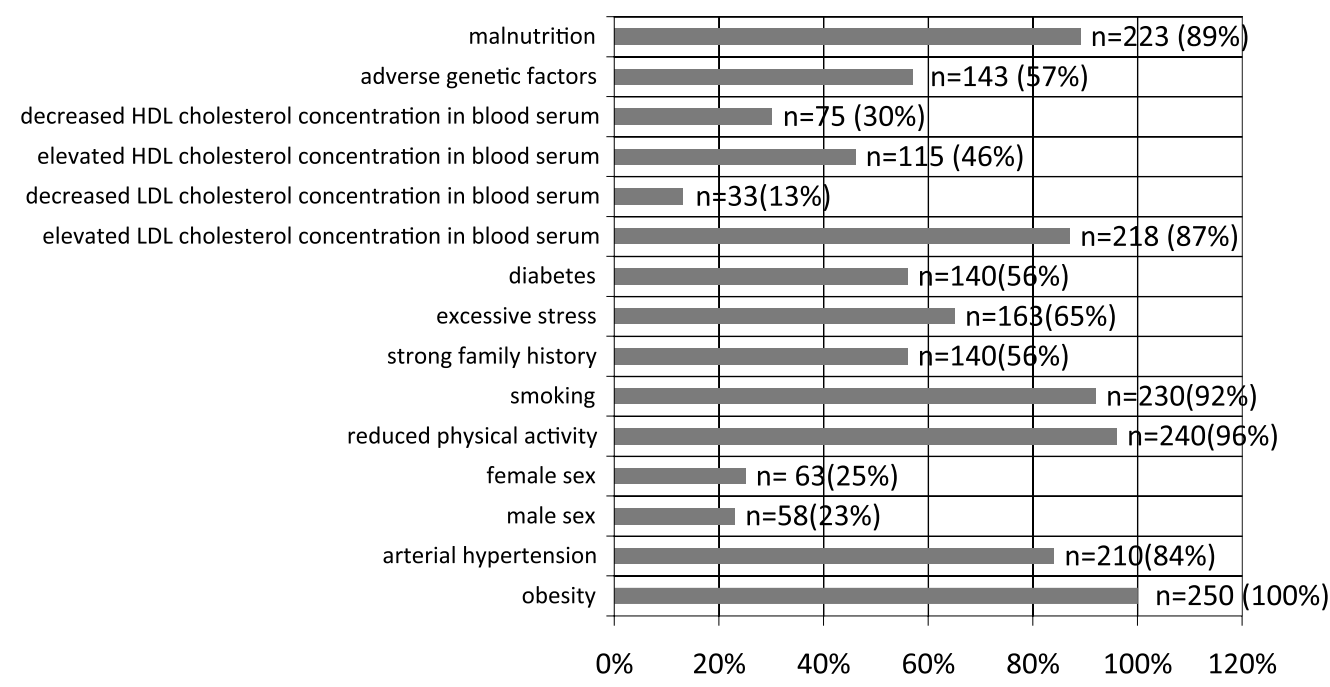

Figure 1. Characteristics of the examined group of first-year medical students with regard to their knowledge on the coronary arteriosclerosis risk factors $(n=250)$

All students were aware that obesity belongs to the group of coronary disease risk factors $(250 ; 100 \%)$, but the fewest respondents knew that being male is also one of those factors $(58 ; 23 \%)$. Unfortunately, a relatively sizeable group pointed to other conditions that do not pose the coronary disease risk factors.

\section{Incidence of coronary arteriosclerosis risk factors in the examined first-year medical students}

The characteristics of the examined students with regard to incidence of coronary disease risk factors are presented in Figure 2. 


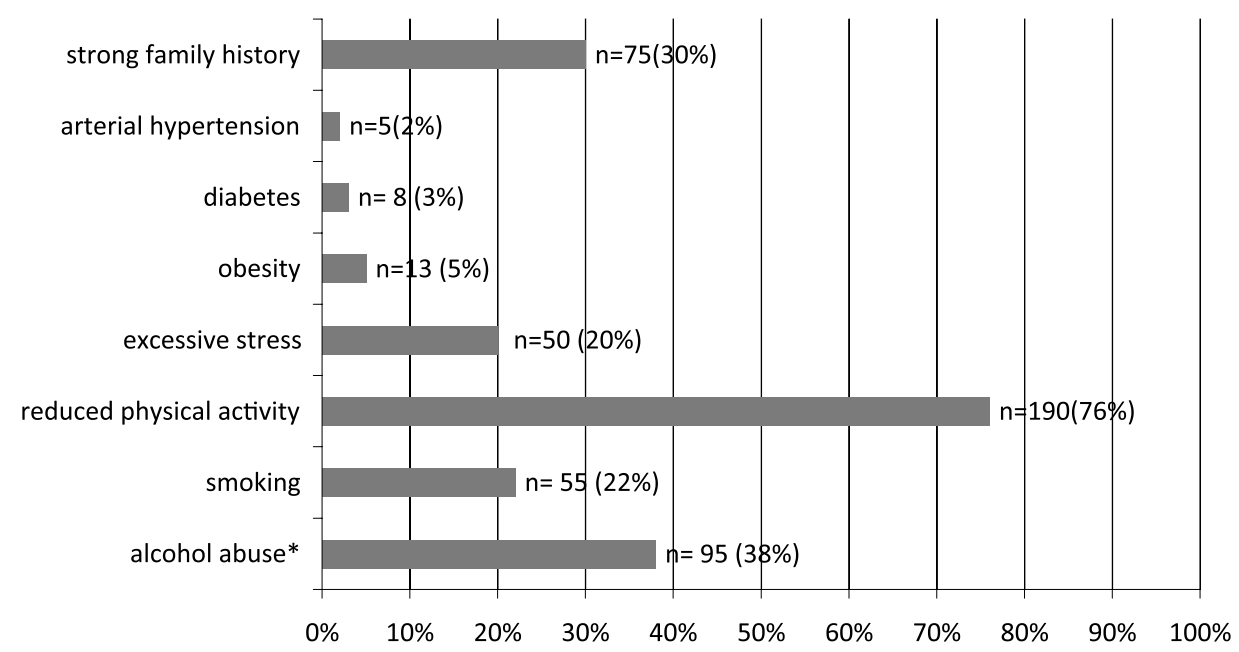

Figure 2. Characteristics of the examined group of first-year medical students with regard to incidence of coronary arteriosclerosis risk factors $(\mathrm{n}=250)$

* consumption of alcohol at least once a week.

The following mostly alterable coronary disease risk factors were identified by the examined first-year medical students: reduced physical activity (190; 76\%), alcohol abuse (95; 38\%), smoking (55; 22\%), and excessive stress $(50 ; 20 \%)$.

\section{Lifestyle of the first-year medical students}

The characteristics of the examined group with regard to frequency of their physical activity amounting to at least 30 minutes are presented in Figure 3.

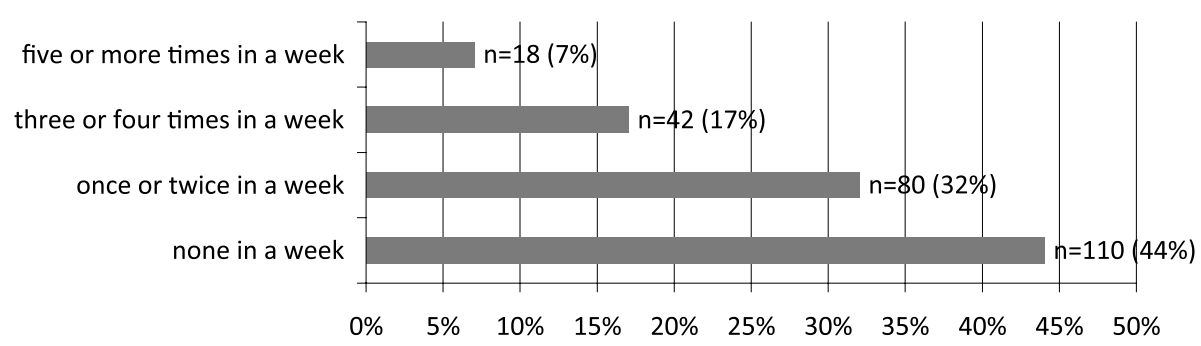

Figure 3. Characteristics of the examined group with regard to frequency of their physical activities reaching at least 30 minutes $(n=250)$

The most numerous group of the examined students do not get involved in physical exercises lasting at least 30 minutes even once a week $(110 ; 44 \%)$, and only some of them do it five or more times per week in the indicated time span $(18 ; 7 \%)$.

The characteristics of the examined students with regard to the number of meals per day are presented in Figure 4.

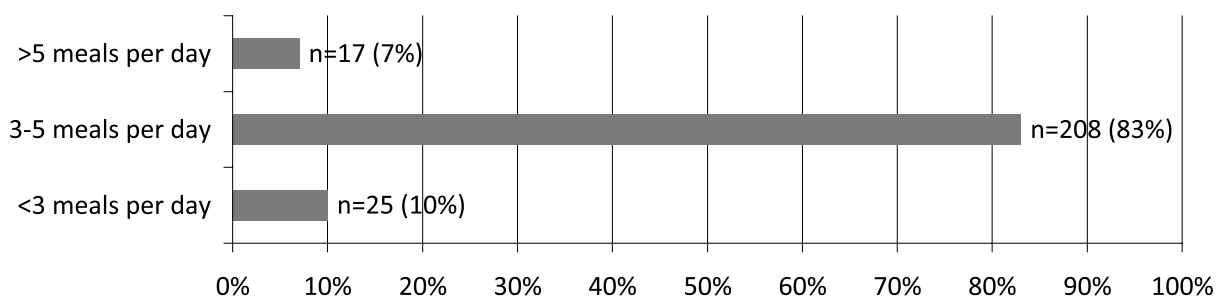

Figure 4. Characteristics of the examined group of first-year medical students with regard to the number of meals eaten during a day $(\mathrm{n}=250)$

Most of the respondents have from three to five meals a day (208; 83\%). 
The characteristics of the examined students with regard to frequency of eating fast-food are presented in Figure 5.

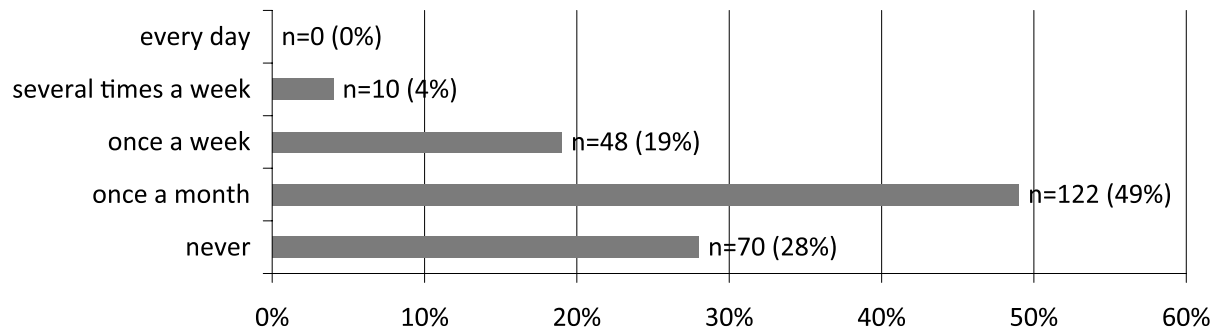

Figure 5. Characteristics of the examined group of first-year medical students with regard to frequency of eating fast-food $(n=250)$

Unfortunately, a significant group of the examined students (180; 72\%) follow an unhealthy diet.

The characteristics of the examined students with regard to the amount of sleep are presented in Figure 6.

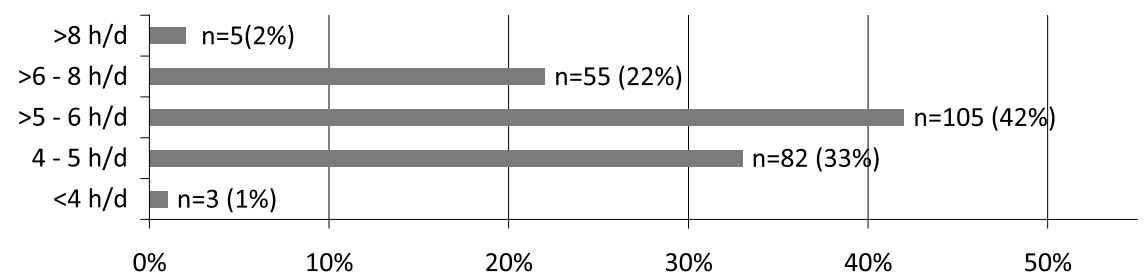

Figure 6. Characteristics of the examined group of first-year medcial students with regard to their amount of sleep (n=250)

A substantial majority of the examined students of the first year of medical studies sleep less than the recommended amount of time $(190 ; 76 \%)$

The characteristics of the examined students with regard to the quality of sleep are presented in Figure 7.

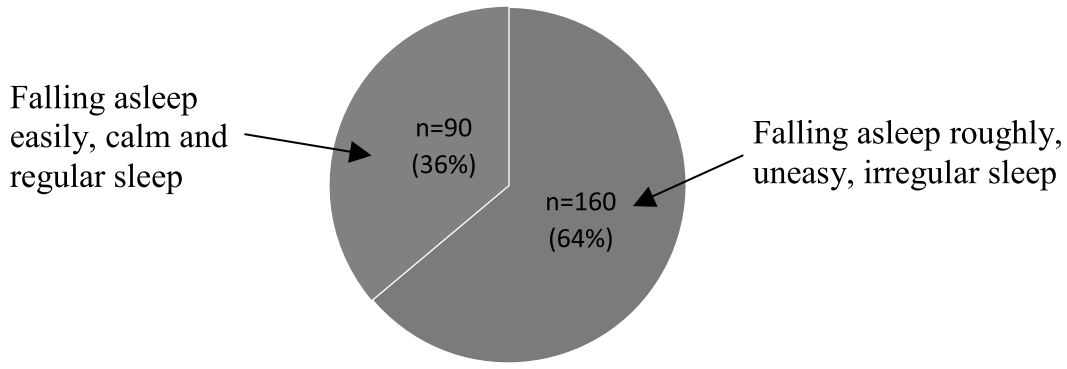

Figure 7. Characteristics of the examined group of first-year medical students with regard to their sleep quality $(n=250)$

More respondents find it hard to fall asleep, and their sleep is uneasy and irregular (160; 64\%).

The characteristics of the examined students with regard to the amount of consumed coffee are presented in Figure 8.

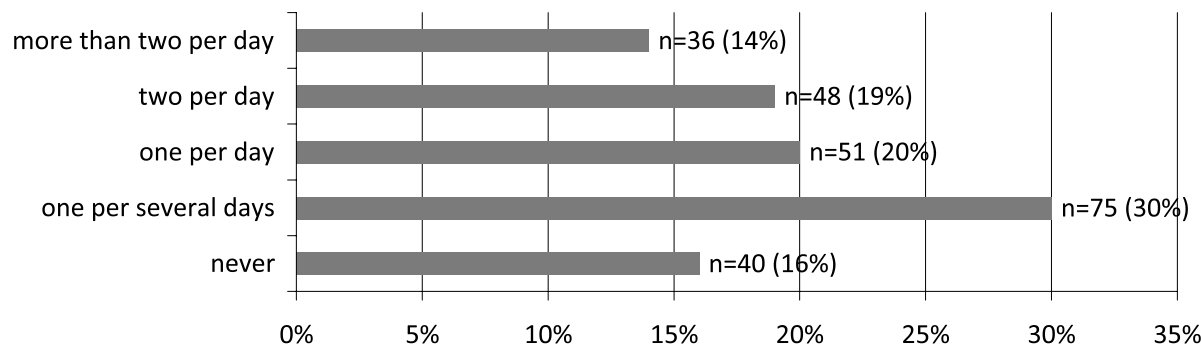

Figure 8. Characteristics of the examined group of first-year medical students with regard to the amount of consumed coffee, expressed in $200 \mathrm{ml}$ cups ( $\mathrm{n}=250)$ 
A significant majority of students drink coffee (210;84\%), and 1 in 3 drinks two or more cups per day (84; $33 \%)$.

Characteristics of the examined students with regard to the number of energetic beverages consumed during a day are presented in Figure 9.

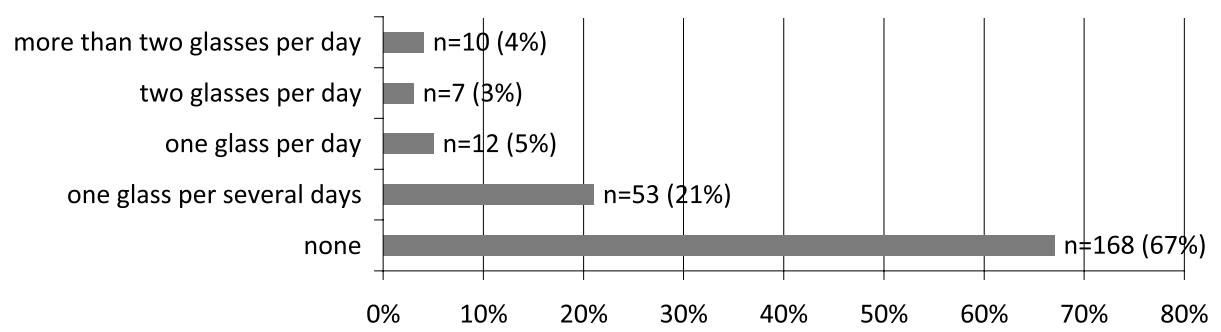

Figure 9. Characteristics of the examined group of first-year medical students with regard to the amount of consumed energetic beverages, expressed in $200 \mathrm{ml}$ cups $(n=250)$

The majority of the tested first-year medical students studies do not drink energetic beverages at all (168; $67 \%)$, but among those who do (82; 33\%), there are also respondents who drink more than two glasses per day $(10 ; 4 \%)$.

The characteristics of the examined students living in a cigarette smoke environment are presented in Figure 10.

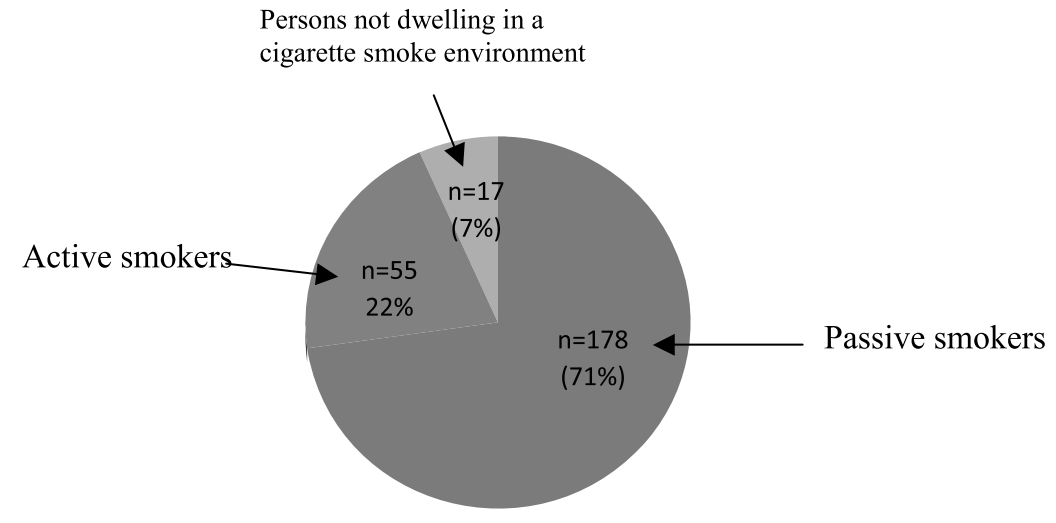

Figure 10. Characteristics of the examined group of first-year medical students with regard to dwelling in a cigarette smoke environment $(n=250)$

More than $90 \%$ of the examined students dwell in a cigarette smoke environment, but the number of active smokers is considerably lower than the number of passive ones (22\% vs $71 \%)$.

The characteristics of the examined students dwelling in a cigarette smoke environment with regard to frequency of smoking are presented in figure 11.

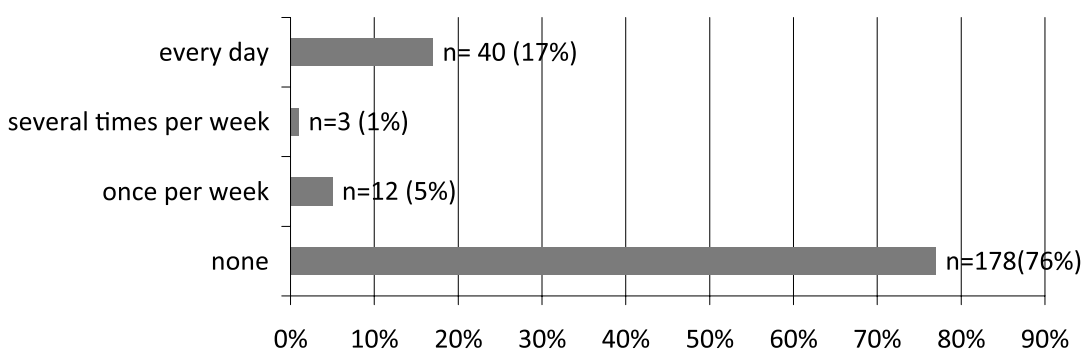

Figure 11. Characteristics of the examined group of first-year medical students dwelling in a cigarette smoke environment with regard to frequency of smoking cigarettes $(n=233)$

The majority of students exposed to cigarette smoke do not smoke cigarettes (178; 76\%).

The characteristics of the examined students with regard to the use of drugs are presented in Figure 12. 


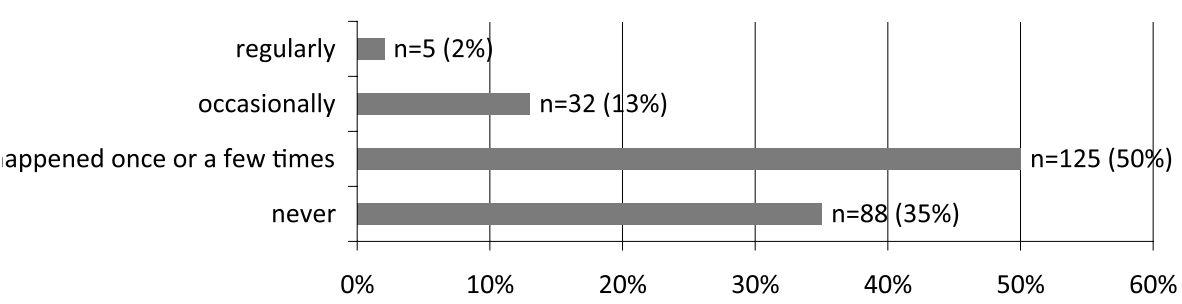

Figure 12. Characteristics of the examined group of first-year medical students with regard to drug use $(n=250)$

As many as $65 \%$ of the examined students "tried" drugs and, unfortunately, there are a few respondents who use the illegal substances regularly (2\%).

The characteristics of the examined students with regard to the frequency of alcohol consumption are presented in Figure 13.

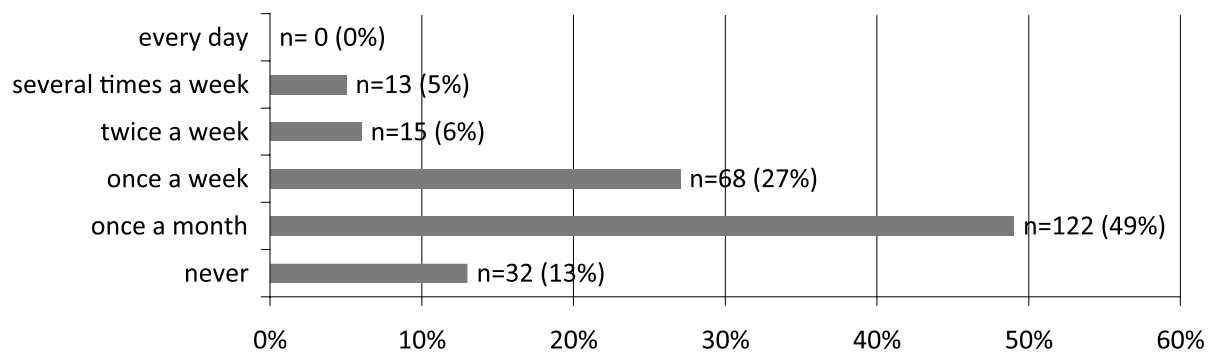

Figure 13. Characteristics of the examined group of first-year medical students with regard to frequency of alcohol consumption $(\mathrm{n}=250)$

Almost $40 \%$ of the tested first-year medical students drink alcohol at least once a week.

\section{Discussion}

Interest in coronary arteriosclerosis risk factors arises from their influence on development and progression of the coronary disease, and the resulting mortality rate. Cardiovascular diseases risk factors have become a subject of numerous scientific papers. The level of knowledge on these factors held by various social groups is presently being_evaluated in order to determine the level of awareness among the general public, to draw people's attention to how the risk factors increase and to the necessity of promoting health and living a healthy lifestyle.

The presented work is an attempt to evaluate the level of knowledge on coronary arteriosclerosis risk factors, and how they arise among the students of the first-year medical studies at the Medical University of Silesia in Katowice. The questionnaire devised by the author was to examine the lifestyles of the surveyed students, which may influence the potential development of cardiovascular diseases in the future. The examined group was not selected randomly. Persons who do medical courses are obliged to undertake pro-health behaviours that would be followed by others. By deepening own medical knowledge, they have several opportunities to promote prohealth behaviours among the general public.

Potvin L. undertook a task to determine the level of knowledge on cardiovascular diseases risk factors in the Canadian population. According to his analysis, only $60 \%$ of the respondents pointed to malnutrition, $52 \%$ smoking, $41 \%$ physical inactivity, $27 \%$ an elevated LDL cholesterol level in blood serum and $22 \%$ - arterial hypertension [8]. In the study conducted in the Venezuelan population, $67 \%$ of the respondents indicated that obesity might be such a factor and $27 \%$ pointed to arterial hypertension. $60 \%$ of the examined individuals declared that they had knowledge on cardiovascular diseases risk factors, and only $15 \%$ identified them correctly [9]. Also, Arredondo proved that the respondents' knowledge in the discussed matter is satisfactory in the studies conducted in the post-graduate medical students. Most of them would point to all coronary disease risk factors correctly [10]. In our studies, the coronary arteriosclerosis risk factors most often selected by the first-year medical students included obesity (250; 100\%), reduced physical activity (240; 96\%), smoking (230; 92\%), malnutrition (223; 89\%), elevated LDL cholesterol concentration in blood serum (218; 87\%), arterial hypertensions $(210 ; 84 \%)$, excessive stress $(163 ; 65 \%)$, strong family history $(140 ; 56 \%)$ and diabetes (140; 56\%). Some students, i.e. 75 (30\%), believed that the decreased HDL cholesterol concentration in blood serum is one of the risk factors. Fewer respondents $(58 ; 23 \%)$ would indicate that being male sex is a coronary 
arteriosclerosis risk factor. Unfortunately, quite a sizeable group of students selected the conditions which are not actually classified as risk factors, such as elevated HDL cholesterol concentration in blood serum (115; 46\%); lowered LDL cholesterol concentration in blood serum (33; 13\%), as well as being female (63; 25\%). When compared to the populations described by other authors, the examined students looked good against others; however, it needs to be borne in mind that they are medical students who should know better.

Despite a satisfactory level of knowledge on the factors facilitating the coronary arteriosclerosis condition, the students themselves exhibit some of the described risk factors especially reduced physical activity (190; $76 \%)$, alcohol abuse $(95 ; 38 \%)$, smoking (55; 22\%), excessive stress (50; 20\%), obesity (13; 5\%), diabetes (8; 3\%) and arterial hypertension $(5 ; 2 \%)$.

As it turned out, the majority of students do not practice sports regularly, which is proved by numerous studies [11-14]. Our results confirmed this as well. Very few students do exercises at least 5 times a week for 30 minutes $(18 ; 7 \%)$. Unfortunately, the biggest group of students do not exercise at all (110; 44\%). Physical inactivity causes that excessive energetic supplies are accumulated as fatty tissue. Further, the students' sedentary lifestyle overloads bones; therefore, resulting in postural deformation. The insufficient physical activity of the examined students, as indicated in the paper, may lead to overweight and obesity especially when combined with wrong eating habits.

As suggested by other researchers, around 1/3 of all students do not eat regularly, and 1 in 5 students do not eat fruit and vegetables, while products rich in carbohydrates are consumed by almost half of the examined students [15-16]. Furthermore, the examined students tend to consume from three to five meals a day (208; 83\%), while 1 in 10 students eats less frequently, i.e. 25 (10\%) and 7\% more often (n=17). Proper daily distribution of meals is of considerable importance for the correct functioning of the organism. It reduces the incidence of overweight and obesity and causes more effective and complete use of food ingredients. Uneven supply of energy and nutritious components may result in lower metabolic rates, contributing to a decrease of concentration, sleepiness, apathy, which is of great significance in case of students.

Furthermore, fast-food meals are widely popular with students. In some regions, they are consumed even by $90 \%$ of students [17]. Our examination suggests that almost half of the students consume such meals once a month (122; 29\%), and almost $1 / 5$ admit that they visit such fast-food venues more often, i. e. at least once a week (58; 23\%). It needs to be borne in mind that fast-foods are, first of all, a source of calories and fat. If the fat is repeatedly heated, it emits harmful substances, for example, lipid peroxides, which accelerate atherosclerotic and carcinogenic processes. Such fat, despite its plant origin, abounds in trans fatty acids. They are as harmful to the body as the saturated fatty acids of animal origin, which means that they elevate the LDL cholesterol level, and reduce the HDL cholesterol concentration in blood serum.

The studies researching the duration of students' sleep show that its amount varies [18]. In the examined group of the first-year medical students, there were both some sleep more than 8 hours per day (5, 2\%), which is the recommended amount of sleep, as well as those, who sleep from 6 to 8 hours (55; 22\%), or less, i.e. from 5 to 6 hours $(105 ; 42 \%)$, or 4 to 5 hours $(82 ; 33 \%)$ per day. Among the examined students there was also a group of respondents who slept less than 4 hours per day $(3 ; 1 \%)$. In our study, we proved that only $36 \%$ (n=90) of the students sleep calmly and fall asleep without any problems. It is a worrying phenomenon as disturbed, irregular and short sleep influences people's mental condition. Sleepy individuals become more nervous and are influenced by stress more quickly. Thus, neglecting sleep may lead to cardiovascular diseases, for example, arterial hypertension.

As for beverages, it is coffee that is drunk most frequently by students. Many of them drink it every day, even several cups [19]. In our examination, we found out that only $16 \%(40 ; 16 \%)$ of the students do not drink coffee at all, almost $1 / 3$ of students drink one coffee some days a week $(75 ; 30 \%)$, and more than a half of them drink it every day (135; 53\%). 20\% of the respondents $(n=51)$ have two coffees per day, and 33\% (n=84) drinks even more. A prevailing assumption was that there is a need to cut down on the amount of drunk coffee, as it contains caffeine, responsible for hypertension and heart diseases; however, it was proven that its moderate consumption does not need to exert an adverse influence on the cardiovascular system. Only when an individual consumes 4 cups of coffee per day, there may be an increased risk of coronary incidents, when compared to those drinking less than one cup per day [20-21].

The examinations carried out in the USA showed that most students drink energetic beverages, and almost half of them do it regularly [22]. Our study results were similar. Nearly $70 \%$ of students do not drink such beverages at all $(168 ; 67 \%)$, and $21 \%$ drink around one cup a week $(n=53)$. The remaining respondents do it more often $(29 ; 12 \%)$. The energetic beverages elevate blood pressure and increase its viscosity, contributing to clots, which may lead to a brain stroke and heart attack.

The previous studies related to smoking in students found that a sizeable group of young people "tried" cigarettes, and many of them smoked habitually. A significant number of students are exposed to cigarette smoke 
[23-24]. Similar results were obtained in our studies as the majority of students from the researched group do not smoke cigarettes at all (195; 78\%), quite a sizeable group smokes regularly $(55 ; 22 \%)$, and the majority smoke all the time $(40 ; 16 \%)$. Almost all the examined students are exposed to cigarette smoke (233; 93\%). Thus, it seems that avoiding tobacco and staying in a smoke-free environment become significant elements of a healthy lifestyle. Currently, cigarette smoking is a leading cause of premature death in the developed countries. Further, passive smoking causes the same complications as active smoking, including lungs cancer, cardiovascular diseases and such conditions as chronic obstructive lung disease, bronchitis and asthma.

Furthermore, studies on student behaviour show that many of them try drugs. Students most frequently use marijuana and cocaine, with cocaine and designer drugs remaining less popular [25-26]. In the study, we proved that as many as $65 \%$ of the first-year of medical students tried drugs $(162 ; 65 \%)$. Half of the whole student group did it once or several times $(125 ; 50 \%)$, while the others would use drugs occasionally $(31 ; 13 \%)$. Unfortunately, there was also a group of the respondents who used drugs regularly (5; $\%)$. As for the cardiovascular system, drugs and designer drugs may accelerate the heart rate significantly and cause arrhythmia, for example, atrial fibrillation. They may also significantly increase arterial pressure and, as a consequence, cause cerebral hemorrhage, a heart attack or heart failure.

Finally, the study findings, indicate that young people use alcohol quite often. In another population of young people of Chile, as many as $85 \%$ admitted to drinking alcohol. Most of them stated that they had drunk alcohol within the last month [18]. Our questionnaire findings indicate that the students consume alcohol in similar amounts as the young Chileans, i.e. nearly half of them did it once a month (122; 49\%), a little more than $1 / 4$ of the respondents admitted to drinking alcohol once a week (68;27\%), and 1 in 20 students drink more frequently $(13 ; 5 \%)$. Alcohol abuse plays a significant role in the development of cardiovascular diseases, disturbing rhythmicity of heart, lipid metabolism of the organism, and increasing blood pressure.

Summing up, it needs to be emphasised that the examined group was composed of first-year medical students, who are expected to possess extensive knowledge and awareness in the field of pro-health behaviour. The respondents' knowledge concerning coronary disease risk factors may be assessed as satisfactory; however, promoting healthy lifestyles to eradicate risk factors needs improving. The risk factors identified in the examined students are modifiable; hence their elimination, depending on one's behaviour, may reduce the probability of developing cardiovascular diseases in the future.

\section{Conclusions}

1. Level of knowledge in the examined students on the coronary arteriosclerosis risk factors is satisfactory, except for such factors as " being male" and "HDL cholesterol concentration".

2. Despite the satisfactory level of knowledge on the risk factors, their incidence in the examined group is significant.

3. Majority of the examined students live a healthy lifestyle. Still, there are too many individuals who smoke and live a sedentary lifestyle, which when combined with malnutrition and energetic beverages may suggest that they, as future doctors, need to be educated in terms of model healthy attitudes.

\section{References:}

1. Vishrama J, Borglykkeb A, Andreasenb A, Jeppesen J, Ibsen H, Jorgensen T, et al. Do other cardiovascular risk factors influence the impact of age on the association between blood pressure and mortalisty? The MORGAM Project. J Hypertens 2014; 32(5): 1025-32. https://doi.org/10.1097/HJH.0000000000000133

2. Rao V, Kiran R. Evaluation of correlation between oxidative stress and abnormal lipid profile in coronary artery disease. J Cardiovasc Dis Res 2011; 2(1), 57-60. https://doi.org/10.4103/0975-3583.78598

3. Batty GD, Shipley M, Smith GD, Kivimaki M. Long term risk factors for coronary heart disease and stroke: influence of duration of follow-up over four decades of mortality surveillance. Eur J Prev Cardiol 2015; 22(9): 1139-45. https://doi.org/10.1177/2047487314547659

4. Pencina MJ, D’Agostino RB Sr, Larson MG, Massaro JM, Vasan RS. Predicting the 30-year risk of cardiovascular disease: the framingham heart study. Circulation 2009; 119(24): 3078-84. https://doi.org/10.1161/CIRCULATIONAHA.108.816694

5. Ibrahim NK, Mahnashi M, Al-Dhaheri A, Al-Zahrani B, Al-Wadie E, Aljabri, et al. Risk factors of coronary heart disease among medical students in King Abdulaziz University, Jeddah, Saudi Arabia. BMC Public Health 2014;28(4): 14-411. https://doi.org/10.1186/1471-2458-14-411

6. Arts J, Fernandez ML, Lofgren IE. Coronary heart disease risk factors in college students. Adv Nutr 2014; 5(2): 177-87. https://doi.org/10.3945/an.113.005447 
7. Chromiński K, Tkacz M. Comparison of outlier detection methods in biomedical data. JMIT 2010; 16: 89-94.

8. Potvin L, Richard L, Edwards AC. Knowledge of cardiovascular disease risk factors among the Canadian population: relationships with indicators of socioeconomic status. CMAJ 2000; 162(9): 5-11.

9. Querales M, Ruiz N, Rojas S, Espinoza M. The level of knowledge concerning cardiovascular risk factors in people living in Naguanagua, Venezuela. Rev Salud Publica (Bogota) 2011; 13(5): 759-71.

10. Arredondo J, Herranz A, Saiz R ,Vázquez I, Beunza JJ, López del Burgo C. Medical students knowledge of cardiovascular risk factors. Rev Med Univ Navarra 2007; 51(4): 3-8.

11. Awadalla NJ, Aboelyazed AE, Hassanein MA, Khalil SN, Aftab R, Gaballa II, et al. Assessment of physical inactivity and perceived barriers to physical activity among health college students, south-western Saudi Arabia. East Mediterr Health J 2014; 20(10): 596-604.

12. Rangel Caballero LG, Rojas Sánchez LZ, Gamboa Delgado EM. Overweight and obesity in Colombian college students and its association with physical activity. Nutr Hosp 2014; 31(2): 629-36. https://doi.org/10.3305/nh.2015.31.2.7757

13. Ali M, Yusuf HI, Stahmer J, Rahlenbeck SI. Cardiovascular risk factors and physical activity among university students in somaliland. J Community Health 2015; 40(2): 326-30. https://doi.org/10.1007/s10900-014-9938-3

14. Vorhees J, Goto K, Wolff C. Overweight, elevated blood pressure, acanthosis nigricans and adherence to recommended dietary and physical activity guidelines among Hmong and white middle school students. J Immigr Minor Health 2014; 16(2): 273-9. https://doi.org/10.1007/s10903-012-9739-7

15. Chemperek E, Jeleniewski M. Digestive system diseases and style of nutrition among secondary school students. Pol Merkur Lekarski 2001; 10(57): 153-5.PMID:11398515

16. Bakr EM, Ismail NA, Mahaba HM. Impact of life style on the nutritional status of medical students at Ain Shams University. J Egypt Public Health Assoc 2002; 77(1-2): 29-49.

17. Shah T, Purohit G, Nair SP, Patel B, Rawal Y, Shah RM. Assessment of obesity, overweight and its association with the fast food consumption in medical students. J Clin Diagn Res 2014; 8(5): 5-7. https://doi.org/10.7860/JCDR/2014/7908.4351

18. Ming X, Koransky R, Kang V, Buchman S, Sarris CE, Wagner GC. Sleep insufficiency, sleep health problems and performance in high school students. Clin Med Insights Circ Respir Pulm Med 2011; 5: 71-9. https://doi.org/10.4137/CCRPM.S7955

19. Górnicka M, Pierzynowska J, Kaniewska E, Kossakowska K, Woźniak A. School pupils and university students surveyed for drinking beverages containing caffeine. Rocz Panstw Zakl Hig 2014; 65(2): 113-7.

20. Bielesz K, Strzelczyk W, Poniewaz M, Sokołowski F, Welsyng D, Rucińska M, et al. The effect of coffee on blood pressure at healthy subjects. Pol Merkur Lekarski 2013; 35(207): 133-5.

21. Mostofsky E, Rice MS, Levitan EB, Mittleman MA. Habitual coffee consumption and risk of heart failure: a dose-response meta-analysis. Circ Heart Fail 2012; 5(4): 401-5. https://doi.org/10.1161/CIRCHEARTFAILURE.112.967299

22. Terry-McElrath YM, O’Malley PM, Johnston LD. Energy drinks, soft drinks, and substance use among United States secondary school students. J Addict Med 2014; 8(1): 6-13. https://doi.org/10.1097/01.ADM.0000435322.07020.53

23. Arrazola RA, Neff LJ, Kennedy SM, Holder-Hayes E, Jones CD; Tobacco use among middle and high school students--United States, 2013 MMWR Morb Mortal Wkly Rep 2014; 63(45): 1021-6.

24. Zielińska-Bliźniewska H, Młódzik J, Olszewski J. Evaluation of tobacco smoking addiction and passive exposure to tobacco smoke in students of medicine. Pol Merkur Lekarski 2011; 31(186): 353-6.

25. Van der Poel A, Rodenbur G, Dijkstra M, Stoele M, van der Mheen D. Trends, motivations and settings of recreational cocaine use by adolescents and young adults in the Netherlands. Int J Drug Policy 2009; 20: 143-51. https://doi.org/10.1016/j.drugpo.2008.02.005

26. Seidler T, Szczuko M. Nutrition mode evaluation among University of Agriculture students in Szczecin in 2006. Part III. Coffee, tea, alcohol, smoking. Rocz Panstw Zakl Hig 2009; 60(3): 241-5. 